aspect and well balanced in his estimates of present damage and future risks. He is really more concerned with air pollution where smoke reduction is accompanied by increase in $\mathrm{SO}_{2}$ with the petrol engine more lethal than the diesel. $\mathrm{He}$ is less informative about pollution of fresh waters (where indeed there are other sources of knowledge) and still less about the sea. However, the effects of the Torrey Canyon may well be more beneficial than harmful if we are shocked into organisation of adequate measures against further risks of oil pollution.

Within the covers of a relatively short book, the author could hardly have done better.

C. M. YONGE

\title{
Darwin and Henslow. The growth of an idea. Letters 1831-1860. Edited by Nora Barlow. John Murray, 35s.
}

This is a happy book. It consists of letters forthright and as fresh as yesterday. The first explodes with the zest of a young naturalist who has just completed his formal education. Where it will lead, who could tell ? They proceed with gathering experience, wisdom and bliss until, after 30 years, there comes one of the least known, yet one of the greatest, Letter 114; it culminates the triumphant friendship which established modern thought. We see the vivacious actor, Charles Darwin, impromptu in his career; we hear the studious prompter, John Stevens Henslow, reminding him of his audience, almost as author directing the drama. Who was this divine who steered the young man from the Church into a path that was mistaken for unholy and vindicated him? Footnotes, bibliography and appendices do not wither with erudition but magnify the intimacy of these two manifold lives which grow in the imagination.

Various of these letters have appeared before, but not in this stark sequence which is their thrill. The fun of life runs through them all, for that recluse old man draped in his black cloak had the sprightliest mind. If one has not read The Voyage of the Beagle or The Origin of Species, these letters will entice; and, having enjoyed this little book, one will need possess it.

E. J. H. CORNER

\section{Great Waters, by Alister Hardy. Collins, 63s.}

This book is based on Sir Alister Hardy's journal when he was Chief Zoologist aboard the RRS Discovery, a sailing ship with only a steam auxiliary, during an expedition to the Southern Ocean in 1925-27. The aim of the voyage was to study the biology of whales and the relevant oceanography of the seas in the region bounded by the Falkland Islands, South Georgia, the South Orkneys, South Shetlands and Cape Horn, with regard to the preservation of the whaling industry. The work was to be analogous to that carried out by fishery scientists in European seas since about 1900.

The narrative of the voyage is broken in places by accounts of the results obtained, largely in the form of summaries of the Discovery Reports; even so, it seems to drag at times, but it does show well the atmosphere of this pioneer voyage: the tediously long spells of hard routine work, the frustrations due to bad weather, the hazards of ice and shortage of fuel, the need for improvisation with scientific equipment and so on. Sir Alister's synthesis of the results shows clearly the ecosystem which supported the huge whale stocks. He also gives us an eye-witness account of the whaling industry in the $1920 \mathrm{~s}$, but he deals too briefly with the question of how it was able to develop so as to reduce some species to near extinction.

Fisheries scientists aim to collect enough data from which to calculate the best sustainable yield from a stock of whales or fish. In the case of the Southern Ocean whales it was difficult to carry out tagging and ageing, two of the techniques used 
to determine mortalities, and it was only with the application of the mathematical treatment of catch statistics developed for fish stocks that the best yields could be resolved. But this was at the eleventh hour. It might be asked whether earlier numerical assessment of the stocks might not have saved them. It is unlikely: political considerations would probably still have been paramount. Nevertheless, if they are to give sound advice, fisheries scientists must make sure that their science remains in equilibrium; studies in physical and biological and oceanography, to give the essential basic information about the biology of fish and about their physical and biological environments, must be balanced against the less glamorous study of fish population dynamics.

A. J. LEE

\section{Seals of the World by Gavin Maxwell, with John Stidworthy and David Williams. Constable, 25 s.}

The first chapter is a straightforward and enjoyably readable introduction to the natural history of seals, their fascinating habits, their extraordinary metabolism by which they adjust perfectly to both hot sun on land and ice and deep diving activity in near-freezing water. The second chapter describes briefly the collision between seals and man, resulting in four of the 32 species of seals, sea-lions and walrus being in grave danger of extinction; one, the Caribbean monk seal, is probably already extinct. The walrus and the Mediterranean monk seal need total protection for a good many years to come, but are not getting it. Most of the remaining species are at present not seriously decreasing, thanks to a new and more enlightened policy of prohibition or regulation of hunting by the governments concerned.

The remaining chapters are potted life histories of each species. I picked out many entertaining and curious items, such as: once-a-week suckling over nearly a year's lactation (Cape fur seal); the walrus wears a natural Mae West (inflatable neck pouches) enabling it to support its great tusks and float upright while dozing at sea; sea elephant intestines can be over an eighth of a mile long. Inevitably, in dipping into the vast literature for their facts, the authors have perpetuated a number of inaccuracies; these ought to be eliminated in future editions of this attractive volume, the sales of which are to benefit the World Wildlife Fund, under whose sponsorship it is published.

R. M. LOCKLEY

\section{Penguins by John Sparks and Tony Soper. David and Charles, Newton Abbot, 45s.}

Although penguins have been subjected to all kinds of intensive study in the last 20 years there has been no general account of their biology; and so much has now been discovered that Murray Levick's delightful Antarctic Penguins no longer tells more than a small fraction of the story.

The author's opening 30-page chapter, 'Penguins as birds', which discusses the main ways in which penguins are adapted to their special way of life, is full of things that will be new to most readers, and offers illuminating comparisons with other birds. The succeeding chapters, on courtship, nest-making, family life, food and predators, although full of interest do not quite maintain the same standard, which is not entirely the fault of the authors. In a group of highly specialised animals such as penguins it is the essential specialisations, which are common to them all and make them different from all other animals, that are the most interesting things about them. When one comes down to smaller differences between the species, especially if they have to be described at second hand, it is hard to maintain the same level of interest, and the material in these middle 